\title{
IMPLEMENTASI YURIDIS TERHADAP PELAKSANAAN HAK PENDIDIKAN ANAK DIDIK PEMASYARAKATAN PELAKU PEMBUNUHAN SANTRI DI LAMONGAN
}

\author{
Siti Dalilah Candrawati \\ Universitas Islam Negeri Sunan Ampel Jl. A. Yani 117 Surabaya \\ E-mail: dalilahcandra@gmail.com
}

\begin{abstract}
This paper is a bibliographical research on how the implementation of children's educational rights in the Children Development Institution of Blitar who is underwent criminal sanction for involvement in the murder of a student in Lamongan and how the application of legislation on educational rights of the students. The prisoners who are convicted of murdering student in Lamongan must undergo a 1 year term in LPKA of Blitar. During the sentence, LPKA Blitar has implemented a system of treatment of students through 4 (four) stages, namely 0-1/3 MP, 1/3-1/2MP, 1/2/3 MP, 2/3 to free. During that time they got the right to attend their formal high school and non-formal education in LPKA, even 4 (four) children who were sitting in class XII strived to follow UNAS (national post test) at their own school and passed it well. Because their behavior in LPKA was well assessed by the Penetration Monitoring Team (TPP), it was granted conditional leave (CB) rights so that the criminal sanction was reduced by one third and after 8 (eight), they were transferred to Anta Sena Magelang institution to undergo rehabilitation. In order to obtain optimal results, LPKA of Blitar cooperates with related offices, both with the national education office of Blitar city and NGOs as well as civic organizations. In addition, the implementation of educational rights in LPKA of Blitar, juridically implements articles 1, 2, 3, 4, and 85 of the Act. No. 11 of 2012 on the Criminal System for Children and article 1, 9, 14, 23, 24 Act. No. 35 of 2014 on Amendments to the Law. No. 23 of 2002 concerning Child Protection.
\end{abstract}

Keywords: implementation, prison students (andikpas), Educational institution for Children (LPKA), education and guidance, and the system of treatment of students

Abstrak: Artikel ini membahas tentang implementasi yuridis terhadap pelaksanaan hak pendidikan anak didik pemasyarakatan pelaku pembunuhan santri di Lamongan, yang mana anak didik tersebut menjalani masa tahanannya di Lembaga Pembinaan Khusus Anak Blitar Jawa timur. Para anak didik pemasyarakatan yang dihukum karena didakwa membunuh santri di Lamongan harus menjalani masa pidana selama 1 (satu) tahun di LPKA Blitar, mereka berjumlah 11 (sebelas) orang anak siswa SLTA swasta di Lamongan yang juga menempuh pendidikan tahfidh al-Qur'an (hafal 1-10 juz). Selama masa hukuman, LPKA Blitar telah melaksanakan sistem perlakuan terhadap anak didik melalui 4 (empat) tahap yakni masa 0-1/3 MP, masa 1/3-1/2 MP, masa 1/-2/3 MP, dan

AL-HUKAMA

The Indonesian Journal of Islamic Family Law Volume 08, Nomor 02, Desember 2018; ISSN:2089-7480 
masa 2/3 hingga bebas. Selama masa tersebut mereka memperoleh haknya untuk bersekolah di SMA YP dan mengikuti sekolah Madrasah Diniyyah di dalam LPKA, bahkan 4 (empat) yang sedang duduk di kelas XII diupayakan untuk mengikuti UNAS di sekolah asal dan dinyatakan lulus dengan baik. Karena prilaku mereka di LPKA selama masa pidana dinilai oleh Tim Pemantau Pemasyarakatan (TPP) progressnya baik terus, maka pada tahap akhir masa penahanan mereka semua memperoleh hak cuti bersyarat (CB) sehingga masa pidananya diputuskan dikurangi sepertiga, dan sesudah dijalani selama 8 (delapan) bulan, mereka mutasi ke lembaga Anta Sena Magelang untuk menjalani rehabilitasi. Dalam pembinaan anak didik ini, LPKA Blitar bekerjasama dengan dinas pendidikan nasional kota Blitar, LSM dan Organisasi kemasyarakatan dalam penyelenggaraan Madrasah Diniyah bersinergi PD 'Aisyiyah kota Blitar. Pelaksanaan hakhak pendidikan bagi anak didik pemasyarakatan yang telah dilaksanakan oleh LPKA Blitar tersebut secara yuridis merupakan penerapan pasal 1,2,3,4, dan 85 UU No 11 Tahun 2012 tentang sistem Peradilan Pidana Anak dan pasal 1, 9, 14, 23,24 UU No 35 Tahun 2014 tentang Perubahan atas UU No 23 tahun 2002 tentang perlindungan Anak.

Kata kunci: Anak Didik Pemasyarakatan, Hak Pendidikan, Lembaga Pembinaan Khusus Anak (LPKA).

\section{Pendahuluan}

Konsideran UU No 11 Tahun 2012 tentang Sistem Peradilan Pidana Anak, menyatakan anak merupakan amanat dan karunia Tuhan Yang Maha Esa yang memiliki harkat dan martabat sebagai manusia seutuhnya. Maka untuk menjaga harkat dan martabatnya, anak berhak mendapatkan perlindungan khusus terutama perlindungan hukum dalam sistem peradilan. Indonesia sebagai negara yang mengatur prinsip perlindungan hukum terhadap anak, mempunyai kewajiban untuk memberikan perlindungan khusus terhadap anak yang berhadapan dengan hukum, yaitu perlindungan yang diatur tata caranya oleh perundang-undangan terhadap anak yang sedang terkena kasus hukum diberi sanksi hukuman pemasyarakatan di lembaga pembinaan khusus Anak (LPKA).1

Secara definitif pasal 1 ayat (2) UU No 11 Tahun 2012 tentang Sistem Peradilan Pidana Anak disebutkan bahwa anak yang berhadapan dengan hukum adalah anak yang berkonflik dengan hukum, anak yang menjadi korban tindak pidana, dan anak yang

1 Siti Dalilah Candrawati “Konvensi Hak Anak Perspektif Islam”, Jurnal al-Qanun, Vol. 5, Juni 2003. 
menjadi saksi tindak pidana. Yaitu mereka yang telah berusia 12 (dua belas tahun) tahun, tetapi belum berumur 18 (delapan belas) tahun yang diduga melakukan tidak pidana. Karena vonis hakim Pengadilan, mereka kemudian direhabilitasi di Lembaga Pembinaan Khusus Anak (LPKA), guna memperoleh hak-hak pendidikan baik yang bersifat fisikal, mental, intelektual, emosional, dan spiritual.

Membahas permasalahan hak anak yang di Lembaga Pembinaan Khusus Anak (LPKA) pada dasarnya membicarakan berbagai hal yang seharusnya menjadi hak anak didik pemasyarakatan yang sedang menghadapi persoalan yang berhubungan dengan hukum, mulai dari anak sebagai terduga kriminal, terdakwa, hingga diproses hukum pada peradilan anak, dan akhirnya divonis karena terbukti di persidangan peradilan anak ia telah melakukan tindak kriminal. Fakta di Indosesia, anak yang melakukan tindak pidana atau disebut sebagai anak yang berkonflik dengan hukum sebagian besar mendapat vonis penjara, yakni dirumahkan di LPKA. Mereka adalah anak-anak yang memiliki kompleksitas persoalan sebelumnya yang datang dari lingkungan keluarga, sekolah dan lingkungan sosial. Maka penjatuhan pidana penjara diharapkan lebih bijak untuk menghidarkan prilaku yang lebih buruk pada anak, apakah pidana tersebut membahayakan orang tua serta anak yang bersangkutan.2 Di sinilah makna pentingnya perlindungan atas hak-hak anak didik pemasyarakatan, selama masa pembinaan di LPKA, karena sebagai sosok manusia yang belum dewasa tentu mereka belum memiliki kemampuan untuk melindungi hak-haknya, sehingga memerlukan jaminan perundangan agar hak mereka terpenuhi. Seperti disebutkan oleh pasal 3 UU No 11 tahun 2012 tentang Sistem Peradilan Anak bahwa setiap anak selama proses peradilan pidana memiliki hak yang wajib dilindungi dan dipenuhi negara.

Berkaitan dengan hak anak untuk memperoleh perlindungan hukum selama proses peradilan anak ini, maka pelaksanaan perlindungan hak anak yang sedang menjalani masa pembinaan di LPKA ini, kiranya penting untuk diapresiasi. Dalam sebuah penelitian menunjukkan bahwa beberapa tahanan anak pernah

2 Resolusi PBB No 45/112 tahun 1990 tentang pedoman PBB dalam rangka Pencegahan Tindak Pidana Remaja, pasal 46. 
dianiaya selama ditahan, baik penganiayaan dalam tataran psikis maupun fisik. 3 Tahanan Anak yang menjadi korban tindak kekerasan dalam sebuah lembaga pemasyarakatan kebanyakan tidak berani melapor kepada petugas. 4 Yang demikian ini tidak menutup kemungkinan juga terjadi pada LPKA yang ada di Indonesia, yang jumlahnya masih sangat minim, sementara jumlah penghuni LPKA selalu bertambah.

Salah satu fakta temuan di atas menggambarkan adanya permasalahan hukum, bahwa perlindungan terhadap hak anak yang berhadapan dengan hukum masih belum berjalan menurut semestinya sebagaimana diatur oleh perundangan mengenai perlindungan hak anak dalam sistem peradilan pidana anak yang telah mengalami perubahan, dari UU No 3 Tahun 1997 menjadi UU Nomor 11 Tahun 2012 tentang Sistem Peradilan Pidana Anak.

Permasalahan lainnya yang tengah dialami anak-anak di LPKA adalah hak keberlanjutan pendidikan, karena di antara anak didik ada yang putus sekolah, ada yang sedang duduk di bangku sekolah SD, SLTP, SLTA. Dalam konteks ini LPKA Kelas I Blitar, sebagai satu-satunya Lembaga Pembinaan Khusus Anak di Jawa Timur, sejak tanggal 21 Januari 2017 telah mendapatkan amanat untuk membina 11 (sebelas) anak didik yang terlibat kasus pembunuhan santri yang oleh Pengadilan Negeri Lamongan mereka divonis hukuman 1 (satu) tahun penjara dan 9 (sembilan) bulan masa rehabilitasi, tertanggal putusan 13 januari 2017. Mereka semua adalah siswa Sekolah Lanjutan Tingkat Atas (SLTA) yang juga sedang mengikuti program Tahfidl al-Qur'an dan diantaranya terdapat 4 (empat) orang anak didik yang sedang duduk di kelas XII (ke-dua belas) yang saat awal-awal masuk di LPKA Blitar mereka sedang menghadapi UNAS pada tahun ajaran 2016/ 2017.

Sesuai dengan amanat pasal 3 UU Nomor 11 tahun 2012 tentang Sistem Peradilan Pidana Anak, LPKA Blitar sebagai

3 Estu Putri Wilujeng, "Konsep Diri Anak yang Berkonflik dengan Hukum (Studi Kualitatif tentang Anak yang Berkonflik dengan Hukum pada Rumah Tahanan Klas I Surabaya, Medaeng - Sidoarjo)", Makalah, (Surabaya: Departemen Sosiologi Fakultas Ilmu Sosial dan Ilmu Politik Universitas Airlangga), 6.

4 Purnianti, dkk. Analisa Sistem Peradilan Pidana Anak (Juvenile Justice System) di Indonesia, (UNICEF Indonesia: 2006), 157. 
representasi negara mempunyai kewajiban untuk melindunginya dengan memenuhi hak keberlanjutan pendidikan 11 (sebelas) anak tersebut, baik pendidikan formal maupun non formal, di samping hak-hak lainnya yang harus mereka peroleh. Pemenuhan atas hak pendidikan ini penting karena anak yang sedang berkonflik dengan hukum sekalipun tidak boleh terabaikan hak-hak pendidikannya, sebab ini menyangkut masa depan anak. Kehadiran LPKA sebagai lembaga pemasyarakatan yang sengaja disediakan khusus bagi anak, merupakan wadah bagi pembinaan anak agar mereka menggunakan kesempatan selama masa pidananya untuk memantapkan kesadaran dan mempersiapkan bekal bagi perbaikan diri ke depan, dalam hal ini LPKA tidak dibenarkan oleh undang-undang untuk memutus keberlangsungan pendidikan mereka. Sudah semestinya dengan cara menyediakan sarana pendidikan di dalam LPKA sesuai dengan kebutuhan bakat-minat anak didik serta peraturan pendidikan nasional. Semua itu pada dasarnya dilaksanakan dengan memperioritaskan "kepentingan terbaik bagi anak". Berkaitan dengan hal tersebut penulis tertarik membahas tentang Implementasi Yuridis Perlindungan Hak Anak Didik Pelaku Pembunuhan Santri di LPKA Blitar Jawa Timur.

\section{Hakekat Perlindungan Anak}

UU Nomor 35 tahun 2014 tentang Perubahan atas UU Nomor 23 tahun 2002 tentang Perlindungan Anak, menyatakan bahwa anak adalah amanah dan karunia Tuhan Yang Maha Esa, yang dalam dirinya melekat harkat dan martabat sebagai manusia seutuhnya. Anak merupakan tunas, potensi, dan generasi muda penerus cita-cita perjuangan bangsa, memiliki peran strategis dan mempunyai ciri dan sifat khusus yang menjamin kelangsungan eksistensi bangsa dan negara pada masa depan. Agar setiap anak mampu memikul tanggungjawab tersebut, maka ia perlu mendapat kesempatan yang seluas-luasnya untuk tumbuh dan berkembang secara optimal, baik fisik, mental maupun sosial, dan berakhlak mulia, maka perlu dilakukan upaya perlindungan untuk mewujudkan kesejahteraan anak dengan memberikan jaminan terhadap pemenuhan hak-haknya serta adanya perlakuan tanpa diskriminasi. Semua hak anak tersebut harus dipenuhi oleh pihak-pihak yang 
diberi tanggungjawab, yaitu orang tua (keluarga), masyarakat maupun negara.5

Perlindungan anak pada hakekatnya adalah usaha dan kegiatan seluruh lapisan masyarakat dalam berbagai kedudukan dan peranan yang menyadari betul akan pentingnya anak bagi nusa dan bangsa. Jika telah matang pertumbuhan fisik, mental dan sosialnya, tiba saatnya menggantikan peranan generasi terdahulu. Sejalan dengan hal ini, Aris Gosita berpendapat bahwa "perlindungan anak adalah suatu usaha melindungi anak agar melaksanakan hak dan kewajibannya".6

Terdapat 4 (empat) alasan mengapa hak anak perlu dilindungi:

1. Anak tidak dapat berjuang sendiri; ia butuh bantuan orang lain.

2. Kepentingan terbaik anak (the best interest of the child); bahwa anak harus dipandang sebagai of paramount importentce (memperoleh perioritas tertinggi) dalam setiap keputusan yang menyangkut anak.

3. Ancangan daur kehidupan (life-circle approach); diantaranya ada masa-masa penuh resiko, yakni pada usia 12-18 tahun.

4. Lintas sektoral; nasib anak akan bergantung pada berbagai resiko, maka perjuangan terhadap anak adalah perjuangan yang membutuhkan sumbangan semua orang di semua tingkatan.7

Keempat hal tersebut harus menjadi acuan dalam pelaksanaan perlindungan anak, termasuk anak yang berkonflik dengan hukum.8 Dalam perspektif perlindungan anak, seperti yang dinyatakan oleh Hadi Supeno, implementasinya adalah ketika kita selalu menempatkan urusan anak sebagai hal yang paling utama.9

5 Kautsar Muhammad al-Mainawi, Hak. Anak dalam Keluarga Muslim, terj. Moh Suri Sudari (Jakarta: Pustaka al-Kautsar, 1996), 25.

6 Maidin Gultom, Perlindungan Hukum terhadap Perempuan dan Anak, (Bandung: Rafika Aditama, 2012), 97.

7 Ibid.,71-72

8 Perhatikan pasal 1 ayat (2) UU Nomor 11 tahun 2012 tentang Sistem Peradilan Pidana Anak.

9 M. Nasir Djamil, Anak Bukan Untuk Dibukum, (Jakarta: Sinar Grafika Offfset, 2013), 31 . 
Dalam konteks kepentingan terbaik bagi anak, maka kehadiran UU Nomor 11 tahun 2012 tentang Sistem Peradilan Anak perlu disikapi secara positif thinking bahwa anak yang berkonflik dengan hukum diupayakan bisa mendapatkan pembinaan di lembaga pemasyarakatan dengan baik, sehingga besar peluang baginya menjadi manusia yang menyadari kesalahan lalu mengubah prilaku menjadi lebih baik.

Ketentuan hak anak untuk mendapat perlindungan dari berbagai bentuk kejahatan atas dirinya yang telah penulis kemukakan di atas, pada dasarnya sejalan dengan ajaran Islam yang menjunjung tinggi prinsip keadilan dalam berbagai bidang kehidupan, termasuk penegakan nilai-nilai keadilan atas hak anak. Hakekat keadilan adalah tidak berbuat dlalim, karena kedlaliman sama artinya dengan ketidakadilan, di mana ada keadilan maka di situ pula kedlaliman tidak bakal terjadi. Demikian sebaliknya, selama masih ditemukan ketidakadilan maka sampai kapanpun kedlaliman terus merajalela.

Berlaku adil dalam konteks perlindungan anak ini merupakan kewajiban yang sangat dipentingkan oleh Islam. Al-Qur'an menggariskan "Janganlah kebencian terhadap suatu kaum mendorongmu berbuat sewenang-wenang, berlakulah adil karena adil itu lebih dekat kepada taqwa".10 Dalam surat an-Nisa' ayat 135 ditegaskan "Wahai orang-orang yang beriman jadilah kamu orang yang benar-benar penegak keadilan".11 Keadilan yang diperintahkan Islam tidak dibatasi hanya kepada umat Islam saja, melainkan kepada segenap manusia, termasuk kepada anak. Perbedaan ras, suku, bangsa bukanlah dimaksudkan untuk mendorong mereka membanggakan diri karena superioritasnya kepada yang lain. Karena al-Qur'an Surat al-Hujurat ayat 13 menegaskan "Sesungguhnya yang paling mulia di antara kamu di sisi Allah adalah yang paling bertawa".12 Artinya superioritas seseorang atas seseorang yang lain didasarkan atas keimanan, ketakwaan dan moral yang tinggi. Di sini tercermin prinsip kesederajatan sesama manusia yang diajarkan Islam.

10 Perhatikan al-Qur'an surat al-Maidah ayat 8 dalam Al-Qur'an dan Terjemabnya, (Jakarta: Yayasan Penyelenggara Penterjemah/Penafsir al-Qur'an, 1971), 159.

11 Ibid., 144.

12 Ibid., 847. 
Anak sebagai manusia kecil (belum dewasa) juga memiliki hak untuk tidak diperlakukan secara diskriminatif di hadapan anak-nak lainnya, karena kepada mereka juga Allah telah memberikan hak persamaan ini sebagai hak asasi manusia sebagaimana telah diberikan pula kepada manusia pada umumnya.13 Dengan demikian, maka prinsip non diskriminasi dalam memberikan hak-hak anak, baik terhadap anak yang tidak sedang bermasalah maupun anak sedang menghadapi masalah dengan hukum atau lebih dikenal dengan istilah anak yang berhadapan dengan hukum, khususnya bagi anak yang sedang berkonflik dengan hukum pada hakekatnya sejalan dengan prinsip persamaan derajat dalam ajaran Islam.

Melihat berbagai kasus anak, sesungguhnya penerapan hukum pidana kepada anak-anak tidak terlepas dari tujuan hukum pemidanaan, baik dalam pandangan hukum positif maupun hukum Islam. Pandangan ulama hukum Islam telah menjabarkan tujuan pemidanaan, antara lain untuk al-islah (perbaikan)14, dalam konteks al-islah atau pemulihan/perbaikan inilah maka peristiwa hukum 11 (sebelas) orang anak yang divonis hakim dengan hukuman pidana satu tahun penjara karena dipersalahkan telah secara bersama-sama melakukan pembunuhan santri di Lamongan, menjadi penting untuk dicermati, karena mereka sebelum terjadinya kasus kekerasan yang mengakibatkan korban meninggal dunia adalah para siswa Sekolah Lanjutan Tingkat Atas yang sekaligus mengikuti pendidikan Tabfidh al-Qur'an, mereka hafal antara 1 (satu) hingga 10 (sepuluh) juz. Oleh karena itu apabila selama menjalani masa pidana di LPKA Blitar mereka tidak diberikan haknya untuk memperbaiki diri dan melanjutkan pendidikan baik formal SMA YP dan pendidikan non formalnya di Madrasah Diniyah (MADIN) di dalam LPKA, maka masa depan mereka akan terancam menjadi putus sekolah. Padahal amanat yang disebutkan dalam UU Nomor 11 tahun 2012 tentang Sistem Perlindungan Pidana Anak menyatakan bahwa "Anak yang sedang menjalani masa pidana berhak memperoleh pembinaan, pengawasan, pendampingan, pendidikan dan pelatihan serta hak lain sesuai ketentuan peraturan perundang-undangan. Semua hal

13 Maulana Abul A'la Al-Maududi, Hak-hak Asasi Manusia dalam Islam, ter. Bambang Iriana Djayaatmadja (Jakarta: Bumi Aksara,t.t), 19-20. 14 Lihat Q.S. al Maidah (5): 38. 
tersebut adalah menjadi kewajiban LPKA", 15 dan LPKA yang dimaksud dalam penelitian ini ada adalah Lembaga Pembinaan Khusus Anak (LPKA) Blitar Kelas 1 Blitar, yang berlokasi di jln. Bali nomor 76 kota Blitar, satu-satunya LPKA yang berada di Jawa Timur.

\section{Hak Anak dalam LPKA}

Lembaga Pembinaan Khusus Anak (LPKA) adalah lembaga atau tempat Anak menjalani masa pidananya, sedangkan Lembaga Penempatan Anak Sementara (LPAS) adalah tempat sementara bagi anak selama proses peradilan berlangsung. Lembaga ini berfungsi sebagai lembaga atau tempat anak menjalani masa pidananya (usia 12-18 tahun). 16

Berorientasi kepada masa depan anak yang melanggar hukum, maka pemerintah perlu melakukan pembinaan, memberikan bimbingan, pendidikan serta perhatian khusus untuk mereka. Adapun pembinaan yang dilakukan terhadap anak diserahkan kepada pemerintah yang diwujudkan dalam sistem pemasyarakatan. Anak yang berdasarkan putusan pengadilan dijatuhi pidana penjara ditempatkan di Lembaga Pembinaan Khusus Anak untuk menjalani masa pidana sekaligus menerima pembinaan.

Berdasarkan Undang-undang Nomor 11 tahun 2012 tentang Sistem Peradilan Pidana Anak, anak yang berkonflik dengan hukumadalah anak yang berumur 12 (dua belas) tahun, tetapi belum berumur 18 (delapan belas) tahun yang diduga melakukan tindak pidana.17

Istilah Lembaga Pemasyarakatan Anak (Lapas Anak) sudah tidak dikenal dalam Undang-Undang Nomor 11 Tahun 2012 tentang Sistem Peradilan Pidana Anak (UU SPPA) sebagai pengganti Undang-Undang Nomor 3 Tahun 1997 tentang Pengadilan Anak (UU Pengadilan Anak). Setiap Lapas Anak harus

15 Lihat pasal 85 ayat (1) dan ayat (2) UU No 11 tahun 2012.

16 "Anak masih Berpotensi Masuk Rumah Tahanan", dalam http://icjr.or.id/anak-masih-berpotensi-masuk-rumah-tahanan/ diakses pada 11 November 2018.

17 Eric lambue Tampubolon dan Chalid Sahuri, "Efektivitas Pembinaan Narapidana Anak di Lembaga Pembinaan Khusus Anak (LPKA) Pekanbaru", Jom VISIP, Volume 4 No. 1 Februari 2017, 2. 
melakukan perubahan sistem menjadi Lembaga Pembinaan Khusus Anak (LPKA). Pada dasarnya, setiap anak dalam proses peradilan pidana berhak memperoleh pendidikan. Di samping itu, kewajiban anak mengikuti pendidikan formal dan/atau pelatihan yang diadakan oleh pemerintah atau badan swasta merupakan salah satu tindakan yang dapat dikenakan terhadap anak sesuai yang diamanatkan oleh UU SPPA.

Khusus soal anak dalam LPKA (anak yang dijatuhkan pidana penjara), mereka berhak memperoleh pembinaan, pembimbingan, pengawasan, pendampingan, pendidikan dan pelatihan, serta hak lain sesuai dengan ketentuan peraturan perundang-undangan. LPKA wajib menyelenggarakan pendidikan, pelatihan keterampilan, pembinaan, dan pemenuhan hak lain sesuai dengan ketentuan peraturan perundang-undangan. Program pendidikan dan pembinaan ini diawasi oleh Balai Pemasyarakatan (Bapas).

Pengaturan khusus mengenai kepentingan sekolah anak yang berhadapan dengan hukum (termasuk saat menjalankan bimbingan di penjara), diatur berdasarkan Bab III huruf $G$ tentang Tugas dan Wewenang Kementerian Pendidikan Nasional Lampiran Peraturan Menteri Negara Pemberdayaan Perempuan dan Perlindungan Anak Nomor 15 Tahun 2010 tentang Pedoman Umum Penanganan Anak yang Berhadapan dengan Hukum (Permen Pemberdayaan Perempuan dan Perlindungan Anak 15/2010), dikatakan bahwa salah satu tugas Kementerian Pendidikan dan Kebudayaan adalah memfasilitasi penyediaan dukungan sarana/prasarana pendidikan sesuai kebutuhan penyelenggaraan layanan pendidikan bagi Anak yang Berhadapan dengan Hukum $(\mathrm{ABH})$ yang dilangsungkan di dalam LAPAS/RUTAN anak.

Salah satu tugas dan kewenangan dinas pendidikan daerah (provinsi dan kabupaten/kota) dan/atau satuan pendidikan/sekolah dalam penanganan $\mathrm{ABH}$, meliputi $\mathrm{ABH}$ berstatus sebagai tersangka dan ditahan di RUTAN anak atau di kepolisian. Diharapkan dinas pendidikan atau sekolah, orang tua, dan kepolisian atau pihak RUTAN harus tetap mengupayakan anak tidak kehilangan hakhaknya untuk mengikuti setiap kegiatan pembelajaran, termasuk keikutsertaannya dalam evaluasi pembelajaran, seperti ulangan 
harian, ulangan semester, ujian akhir sekolah atau ujian akhir nasional. $18^{[5]}$

Sebagai contoh, berdasarkan sebuah studi tentang penanganan anak yang berkonflik dengan hukum, diketahui bahwa pada beberapa kondisi hunian di LP anak tidak jauh dengan kondisi hunian dewasa, dengan kamar mandi/WC di dalam, dengan alas tidur bervariasi, beralaskan tikar, kasur tipis. Kecuali di LP anak Pare-Pare, dijumpai hunian/kamar anak cukup "child friendly", menggunakan tempat tidur tingkat dan anak bebas menempel gambar-gambar sesuai dengan idola anak-anak remaja. Lebih lanjut dikatakan bahwa hak anak untuk memperoleh pendidikan pada umumnya cukup tersedia, semua LP anak sudah melakukan kejar Paket A, B, dan C (Pendidikan Kesetaraan), serta menyelenggarakan ujian akhir.

Berdasarkan Pasal 4, 5 dan 6 Undang-Undang Nomor 20 tahun 2003 tentang Sistem Pendidikan Nasional (UU Sisdiknas) dapat diketahui bahwa anak yang ditempatkan dalam LPKA juga berhak mendapatkan pendidikan tanpa dibeda-bedakan dan pemerintah bertanggung jawab atas penyelenggaraan pendidikan tersebut. Pendidikan yang diberikan pada anak dapat berupa pendidikan formal, informal maupun nonformal yang dapat saling melengkapi dan memperkaya. Pendidikan formal terdiri atas pendidikan dasar, pendidikan menengah, dan pendidikan tinggi.

Soal pendidikan formal, hasil pemetaan Lapas Anak tahun 2011 dan 2012 tidak semua Lapas Anak dapat menyelenggarakan pendidikan formal, dengan beberapa alasan, yaitu:

a. Terbatasnya jumlah anak yang memenuhi persyaratan mengikuti pendidikan, khususnya lama pidana;

b. Minat anak yang rendah terhadap pendidikan;

c. Fasilitas dan sarana pendukung yang minim dan hampir tidak ada;

d. Rendahnya dukungan dari sekolah anak sebelumnya.

\section{Deskripsi Kasus Pembunuhan Santri di Lamongan yang Dilakukan Anak Didik LPKA}

Pada bulan Desember 2016, masyarakat Indonesia digegerkan dengan kasus penganiayaan yang menyebabkan seorang santri 
Ponpes Muhammadiyah At Taqwa Desa Kranji Kecamatan PaciranLamongan, yang bernama Ahmad Faswas (13 tahun) meninggal dunia. Ia meninggal dunia diduga dianiaya 16 temannya. Korban dituduh mencuri uang dan hard disk pada hari Minggu, 11 Desember 2016. Usai dianiaya, Adam berbaring di kamar. Keesokan harinya, Adam masih terlihat bangun dan menuju kamar mandi namun tak kunjung keluar. Salah satu santri lainnya yang sedang menuju ke kamar mandi menemukan korban pingsan. Mengetahui Adam pingsan, santri lain melaporkan kejadian ke ustadnya dan membawa Adam ke RS Medika Kranji. Namun Adam dirujuk ke Puskesmas Paciran karena diketahui sudah meninggal dunia dan dilakukan autopsi.19

Dari hasil autopsi, di tubuh korban terdapat sejumlah lebam diduga akibat pukulan tangan kosong. Untuk mengungkap dugaan penganiyaan tersebut, pelaku diperiksa di Polsek Paciran. Karena diduga pelaku penganiyaan masih di bawah umur, kasus tersebut kemudian dilimpahkan ke Unit Perlindungan Perlindungan dan Anak (PPA) Polres Lamongan.20

Sebanyak 16 tersangka itu dijerat dengan pasal 80 UU 35 tahun 2004, tentang Perlindungan Anak. Ancaman hukumannya paling lama 15 tahun kurungan penjara. Ke 16 tersangka antara lain berinisial IK (15), warga Kecamatan Palang-Kabupaten Tuban, FF (17), ZH (14), keduanya warga Kecamatan Panceng-Gresik, MBS (16), HA (14), ABP (16), SH (16) dan HHAG (17), kelimanya berasal dari Kecamatan Brondong. Tersangka lainnya, RM (15), AAS (16), NAF (17), AR (17), MN (17) dan DA (15), keenamnya warga Kecamatan Paciran serta AF (17)

19 Eko Sudjarwo, "16 Santri Aniaya Temannya Hingga Tewas, Ponpes di Lamongan Angkat Bicara" https://news.detik.com/berita-jawa-timur/d-3371245/16-santri-aniaya-

temannya-hingga-tewas-ponpes-di-lamongan-angkat-bicara, diakses pada 6 November 2018.

20 Eko Sudjarwo, "Seorang Santri Ponpes di Lamongan Tewas Dianiaya Temannya", https://news.detik.com/berita-jawa-timur/d-3369896/seorangsantri-ponpes-di-lamongan-tewas-dianiaya-temannya, diakses pada 7 November 2018. 
warga Kecamatan Duduksampeyan Gresik dan DM (17), warga Kecamtan Tikung.21

Perkara tersebut diproses di Pengadilan Negeri Lamongan dan setelah melalui tahap persidangan, hakim memutus perkara tersebut dalam Putusan PN Lamongan Nomor 14/Pid.SusAnak/2016/PN.Lmg Tahun 2017.

Setelah memperhatikan pasal 82 Ayat (1) UURI Nomor 35 Tahun 2014 tentang Perubahan atas Undang Undang Nomor 23 Tahun 2002 tentang Perlindungan Anak, Undang Undang RI Nomor 11 Tahun 2012 tentang Sistem Peradilan Pidana Anak, dan Undang Undang Nomor 8 Tahun 1981 tentang Hukum Acara Pidana serta peraturan perundang-undangan lain yang bersangkutan; para hakim memutuskan bahwa bahwa 16 anak tersebut telah terbukti secara sah dan meyakinkan bersalah melakukan tindak pidana "Melakukan Kekerasan terhadap Anak yang menyebabkan meninggal dunia".

Berdasarkan hal tersebut, maka para hakim menjatuhkan pidana kepada 11 anak dengan pidana penjara pada Lembaga Pembinaan Khusus Anak (LPKA) di Blitar selama 1 (satu) tahun dan pidana pembinaan dalam lembaga pada Lembaga Penyelenggara Kesejahteraan Sosial (LPKS) PSMP Antasena di Magelang selama 9 (sembilan) bulan; dan 4 anak dengan pidana pembinaan dalam lembaga pada Lembaga Penyelenggara Kesejahteraan Sosial (LPKS) PSMP Antasena di Magelang selama 10 (sepuluh) bulan; 1 anak dengan pidana pembinaan dalam lembaga pada Lembaga Penyelenggara Kesejahteraan Sosial (LPKS) PSMP Antasena di Magelang selama 6 (enam) bulan.22

\section{Pelaksanaan Hak Pendidikan Anak Didik Pemasyarakatan LPKA Blitar}

Pelaksanaan pemenuhan hak pendidikan 11 (sebelas) anak didik yang menjalani masa pidananya di LPKA Blitar yang divonis

21 "Berkas Perkara Tewasnya Santri di Lamongan Dilimpahkan ke Kejaksaan", https://news.detik.com/berita-jawa-timur/d-3375535/berkas-perkara-

tewasnya-santri-di-lamongan-dilimpahkan-ke-kejaksaan, diakses pada 6 November 2018.

22 Putusan PN Lamongan Nomor 14/Pid.Sus-Anak/2016/PN.Lmg Tahun 2017 
terlibat pembunuhan santri di Lamongan, telah diatur prosedurnya menurut standar perlindungan, pembinaan, dan pemenuhan hak anak didik pemasyarakatan di LPKA. Baik dari aspek pola sistem perlakuan anak didik pemasyarakatan, prinsip-prinsip pembinaan anak didik pemasyarakatan, dan kerjasama LPKA dalam pelaksanaan pembinaan anak didik pemasyarakatan. Menurut keterangan kepala seksi pendidikan dan latihan kerja LPKA Blitar,23 bahwa sejumlah 11 (sebelas) anak didik yang divonis hakim terlibat pembunuhan santri di lamongan, telah diterima LPKA pada tanggal 21 Januari 2017 guna menjalani masa pidana selama 1 (satu tahun) sesuai dengan vonis hakim PN Lamonggan tertanggal 13 januari 2017, namun saat berjalan 8 (delapan) bulan, tepatnya pada tanggal 10 Agustus 2017 mereka dinyatakan bebas bersyarat dan selanjutnya pada tanggal 11 Agustus 2017 dipindahkan ke Lembaga Rehabilitasi Antasena Magelang. Terkait pembinaan anak didik tersebut di atas kiranya perlu penulis kemukakan 3 (tiga) hal penting: Pertama, tentang pola sistem perlakuan anak didik kemasyarakatan LPKA Blitar. Kedua, tentang prinsip-prinsip pembinaan anak didik pemasyarakatan LPKA. Ketiga, tentang kerjasama dan kemitraan LPKA Blitar dalam pembinaan anak didik pemasyarakatan.

1. Pola sistem perlakuan anak didik pemasyarakatan, terdiri dari 4 (empat) tahap:

a. Tahap awal (masa $0-1 / 3 \mathrm{MP}$ )

Setiap narapidana anak yang masuk LPKA dilakukan penelitian tentang identitas diri. Tahap ini merupakan tahap pengamatan, penelitian dan pengenalan lingkungan. Pembinaan pada tahap ini masih dilakukan dalam lembaga pemasyarakatan dan pengawasannya maksimum (maximum security).

Karena para anak didik pemasyarakatan ini adalah para siswa SLTA swasta Islam yang juga mengikuti pendidikan tabfid Qur'an, maka perlakuan terhadap pemenuhan hak pendidikannya berbeda dengan kebutuhan anak didik pemasyarakatan lain yang tidak sedang mengikuti pendidikan menghafalkan al-Qur'an. Pada sidang Tim Pemantau

23 Andik (Kepala seksi Pendidikan dan Pelatihan LPKA Blitar), Wawancara, Blitar, 10 Agustus 2017. 
pemasyarakatan (TPP) ditetapkan bahwa mereka akan bersekolah di SMA YP sedangkan untuk pendidikan tabfidh alQur'annya di Madrasah Diniyah (MADIN). Kedua macam pendidikan ini dilaksanakan di dalam LPKA Blitar. Untuk tahfidhnya, mereka diberi kesempatan melaksanakan sehabis shalat dhuhur dan sehabis shalat maghrib, kegiatan ini penting untuk menjaga hafalan al-Qur'an selama ini.24

b. Tahap Lanjutan Pertama (masa 1/3-1/2 MP)

Masa ini merupakan masa penilaian Tim Pengamat Pemasyarakatan (TPP) terhadap progress anak didik pemasyarakatan LPKA Blitar. Hasil penilaian TPP digunakan untuk menetapkan pembinaan selanjutnya, seperti adanya kemajuan tentang keinsyafan, perbaikan disiplin, kepatuhan pada tata tertib yang berlaku di LPKA Blitar. Dalam konteks ini, anak didik pemasyarakatan diawasi secara medium security.

Pada tahap ini mereka mendapatkan penilaian yang baik, bahkan di antara anak didik pemasyarakatan terdapat 4 (empat) orang anak yang waktunya mengikuti ujian nasional (UNAS) pada kelas XII. Sehingga dilakukan upaya bersama antara LPKA, PD Aisyiyah dan PD Muhammadiyah kota Blitar, melaksanakan koordinasi dan advokasi kepada Dinas Pendidikan Lamongan dan sekolah asal, agar diperkenankan mengikuti UNAS. Akhirnya 4 (empat) orang ini dapat mengikuti ujian nasional (UNAS) di sekolah asal dan di pengumuman mereka dinyatakan lulus UNAS 2017.25

Adapun bagi yang masih kelas X dan XI sekolahnya dilaksanakan di SMA YP yang mengiduk kepada SMA YP kota Blitar, jurusan Ilmu Pendidikan Sosial (IPS) dengan jam belajar: Senin, Selasa, Rabu, Kamis, dan Sabtu dimulai pukul 07.30-10.30 dengan metode tatap muka, sedangkan Madrasah Diniyah (MADIN) diselenggarakan selama 4 (empat) hari, Senin sampai Kamis, dengan mata pelajaran alIslam: al-Qur'an-hadis, Aqidah-Akhlaq, Tarikh dan bahasa Arab, dan Tabfidh al-Qur'an. Untuk sebelas anak didik ini,

24 Nidlam (ANDIKPAS kasus pembunuhan santri Lamongan sebagai ketua kelompok), Wawancara, Blitar, 10 Agustus 2017.

25 Sri Lestari, Wakil Ketua PD ‘Aisyiyah kota Blitar, Wawancara, 10 Agustus 2017. 
pendidikan MADIN dijalani sesudah jam sekolah SMA YP. Pada akhir masa belajar diselenggarakan uijan dan mereka memperoleh Sertifikat MADIN, dilampiri raport penilaian dari para ustadzah.

c. Tahap lanjutan kedua ( masa 1/2-2/3 MP)

Bagi anak didik yang telah menjalani masa pembinaan $1 / 2$ (seperdua) dari masa pidana sebenarnya hingga $2 / 3$ (dua pertiga), menurut hasil penilaian Tim Pengamat Pemasyarakatan (TPP) raport para andikpas mengalami kemajuan, sehingga pengawasan kepada mereka sudah relatif berkurang (minimum security). Namun demikian mereka masih tetap bersekolah SMA YP di dalam LPKA yang memang dipersiapkan untuk para andikpas yang sedang menempuh pendidikan SLTA. Hal ini menunjukkan tanggungjawab pemerintah terhadap pentingnya keberlanjutan pendidikan bagi para andikpas.

d. Masa tahap akhir (sesudah masa 2/3 MP - bebas)

Masa ini merupakan masa pembinaan dimulai dari berakhirnya masa pembinaan lanjutan sampai dengan berakhirnya masa pidana di LPKA, karena prilaku mereka progessnya baik terus, maka pengawasan di LPKA semakin berkurang (minim securty). Pada tahap ini mereka diberikan kesempatan untuk cuti bersyarat (CB) dengan menyertakan syarat tertentu dan selanjutnya pada akhir bulan kedelapan masa tahanan mereka sudah dibebaskan.

2. Prinsip-prinsip pembinaan anak didik pemasyarakatan

LPKA Blitar dalam melaksanakan pembinaan dan pembimbingan anak didik pemasyarakatan telah melaksanakan 10 (sepuluh) prinsip pembinaan anak hasil konfrensi "Perubahan Sistem Perlakuan terhadap Anak Berhadapan dengan Hukum yang Ramah Anak Berbasis Budi Pekerti”, sebagai acuan yang mengawal setiap program dan kegiatan pembinaan dan pendampingan anak didik pemsyarakatan. Sepuluh hal tersebut adalah:26

26 Dokumen LPKA Blitar tentang "Piagam Acamanik", Bandung, 4 Agustus 2015. 
a. Anak adalah amanat Tuhan Yang Maha Esa, generasi penerus bangsa wajib mendapatkan kesempatan yang seluas-luasnya untuk dapat tumbuh dan berkembang secara optimal.

b. Penahanan dan penjatuhan pidana penjara bagi anak merupakan upaya terakhir dan dilakukan paling singkat dan dengan memperhatikan kepentingan terbaik bagi anak.

c. Tujuan sistem pembinaan dan pembimbingan anak adalah keadilan restoratif berbasis budi pekerti.

d. Pemberian pidana penjara bukan merupakan bentuk balas dendam dari negara.

e. Selama menjalankan pembinaan dan pembimbingan tidak boleh diasingkan dari keluarga dan masyarakat.

f. Dalam proses pembinaan dan pembibingan anak berhak mendapatkan perlindungan dari kekerasan dan segala bentuk diskriminasi lainnya sesuai dengan harkat dan martabat kemanusiaan.

g. Pendidikan merupakan intisari pembinaan dan pembimbingan anak dalam rangka meningkatkan kecerdasan, intelektual, emosional, dan spiritual, pengembangan potensi diri serta pelatihan ketrampilan dalam upaya mengembangkan minat dan bakat.

h. Pembinaan dan pembimbingan anak didik wajib diarahkan untuk sesegera mungkin dikembalikan kepada keluarga dan masyarakat dalam bentuk program asimilasi dan reintegrasi.

i. Negara menjamin perlindungan dan pemenuhan hak-hak anak melalui penyediaan sumberdaya dan sarana prasarana yang ramah anak.

j. Pembinaan dan pembimbingan terhadap anak dilaksanakan secara sinergi antara pengasuh, pembimbing kemasyarakatan, keluarga dan masyarakat.

Pada hakekatnya, sepuluh prinsip pembinaan andikpas tersebut mengandung berbagai nilai yang mendasar, meliputi landasan teologis dan yuridis bagaimana perlakuan terhadap anak didik, maksud dan tujuan mulia, tekhnis pelaksanaan, hak-hak anak yang diberikan dimana pendidikan sebagai ujung tombaknya, target dan jaminan pencapaiannya, serta kerjasama 
secara eksternal, semuanya bermuara pada prinsip "demi kepentingan terbaik bagi anak" di LPKA.

Upaya membudayakan mutu pelayanan yang sudah kondusif bagi terciptanya pembinaan anak didik dalam suasana ramah anak, berbasis budi pekerti dan menanamkan sikap optimis bahwa masa menjalani pidana merupakan kesempatan untuk evaluasi diri dan perbaikan atas kesalahan tindakan masa lalu menuju masa depan yang lebih cemerlang, karena kesalahan adalah pelajaran berharga bagi setiap anak karena jika dibiarkan dapat membahayakan bagi tumbuh kembang mereka, kiranya patut untuk diapreasi, terus ditingkatkan dan dilanjutkan oleh siapapun yang menjadi pemegang otoritas LPKA, karena menjadi keniscayaan dalam dunia kedinasan bahwa pada saatnya bakal terjadi pergantian pejabat disebabkan mereka harus menjalani masa purna tugas atau keadaan lainnya.

Asumsi bahwa membiarkan prilaku salah atau pelanggaran norma pada anak akan berakibat membahayakan bagi perkembangannya, hal ini sejalan dengan pandangan Romli Atmasasmita, bahwa dalam teori Juvenile Deliuensy setiap perbuatan atau tingkah laku seseorang anak di bawah 18 tahun dan belum kawin yang merupakan pelanggaran terhadap normanorma hukum yang berlaku serta dapat membahayakan perkembangan pribadi si anak yang bersangkutan.27

Prilaku seorang anak menjadi Deluency ini, dalam teori Association Differencial oleh Sutherland (1966) seperti dikutip oleh Wagiati Sutojo, yang menyatakan bahwa anak menjadi Delinkuen disebabkan oleh partisipasinya di tengah-tengan suatu lingkungan sosial yang ide dan tekhnik delinkuen tertentu dijadikan sebagai sarana yang efisien untuk mengatasi kesulitan hidupnya. Karena itu semakin luas anak bergaul, semakin intensif relasinya dengan anak nakal, akan semakin lama pula proses berlangsungnya asosiasi deferensial semakin besar peluangnya mereka akan benar-benar menjadi anak nakal dan criminal.28

27 M Nasir Djamil, Anak Bukan untuk Dibukum, 35. 28 Ibid., 37. 
3. Kerjasama dan Kemitraan dalam pembinaan anak didik pemasyarakatan

Dalam melaksanakan kegiatan pembinaan anak didik pemasyarakatan, LPKA Blitar telah menjalin kerjasama yang berjalan selama ini dengan para mitra, baik antar kedinasan maupun dengan Ormas, yaitu Dinas Kepolisian dalam program pengawalan mutasi andikpas, Dinas Pendidikan dalam program sekolah formal, Dinas Kementrian Agama dalam program PHBI Dinas Sosial dan Dinas Perindustrian dalam program pelatihan lifeskill, Dinas Kesehatan dalam program pemeriksaan kesehatan, Badan Narkotika Nasional kota Blitar dalam program penanggulangan narkotika, dan kemitraan dengan PD 'Aisyiyah kota Blitar dalam program pendidikan Madrasah Diniyah (MADIN), dengan Sahabat Perempuan dan Anak dalam kegiatan pelatihan literasi dan majalah dinding (mading) dan dinasti Hidayatullah dalam kegiatan kajian keagamaan.

Kami berpendapat bahwa kerjasama yang telah berjalan tersebut di atas perlu ditingkatkan, dan dijaga keberlanjutannya, agar kehadiran LPKA Blitar, tetap dipandang sebagai lembaga yang ramah anak yang bermartabat, berkeadilan, serta menjunjung tinggi Hak Asasai Manusia. Kerjasama \& Kemitraan LPKA Blitar dengan berbagai pihak merupakan strategi LPKA menjadi PLKA unggulan di antara LPKA yang ada di Indonesia.

\section{Implementasi Yuridis atas Hak Pendidikan Anak Didik Pemasyarakatan LPKA Blitar}

Berdasarkan pemaparan di atas tentang penerapan hak pendidikan anak didik pemasyarakatan di LPKA Blitar, maka terdapat beberapa implikasi yuridis mengenai hal tersebut; Pertama, dari segi pola alur sistem perlakuan terhadap andikpas, LPKA Blitar telah menerapkan pasal 2 dan 3 UU Nomor 11 tahun 2012 tentang Sistem Peradilan Pidana Anak dan sejalan dengan penerapan dari penjelasaan pasal 3 huruf ( 1 ) bahwa anak sebagai pemilik hak diperkenankan membawa barang pribadi seperti selimut atau bantal, pakaian sendiri.

Pada tahap awal (0-1/3 masa pidana) LPKA Blitar telah menerapkan pasal 85 mulai ayat $(1,2,3)$ UU Nomor 11 Tahun 2012 tentang Sistem Peradilan Pidana Anak, yaitu para andikpas 
tanpa kecuali menerima pembinaan, pendidikan, dan pengasuhan sesuai dengan keadaan masing-masing anak. Sedangkan pada masa lanjutan awal (1/3-1/2 MP) para andikpas diberi kebebasan lebih luas untuk melakukan kegiatan yang positif dengan sistem pengawasan medium securuty. Kepada para andikpas yang memasuki masa ujian UNAS pada kelas XII mereka diusahakan untuk dapat mengikuti ujian nasional, melalui sinergi dengan Lembaga Perlindungan Anak (LPA) Jawa Timur dan PD 'Aisyiyah kota Blitar serta Dinas Pendidikan kota Blitar mereka berkesempatan ikut UNAS dan dinyatakan lulus dengan baik. Demikian juga dengan pendidikan tabfidh al-Qur'annya tetap berjalan dengan baik hingga berakhir masa penahanannya di LPKA dan mereka memperoleh sertifikat /ijazah Diniyah yang dikeluarkan oleh PD 'Aisyiyah kota Blitar. Yang demikian itu merupakan implementasi dari pasal 85 ayat (3) UU Nomor 11 tahun 2012 tentang sistem Peradilan Anak.

Selanjutnya pada tahap masa $1 / 2-2 / 3$ dan masa 2/3-bebas, berdasar pertimbangan prilakunya yang baik, anak didik yang terlibat kasus pembunuhan santri di Lamongan diberikan kesempatan cuti bersyarat, mereka diberikan kesempatan pulang untuk sementara waktu menemui keluarga, juga diusahakan untuk sedapat mungkin bertemu dengan para guru SMA di sekolah asal serta para ustadz di pesantren tabfidhnya. Hal ini menunjukkan bahwa LPKA Blitar telah menerapkan pasal 4 ayat 1 huruf (f) dan pasal 4 ayat (2) UU Nomor 11 Tahun 2012 tentang Sistem Peradilan Pidana Anak.

Kedua, dari segi penerapan pembinaan andikpas, LPKA Blitar telah menerapkan 10 (sepuluh) prinsip pembinaan bagi anak sebagaimana dalam piagam Arcamanik. kesepuluh prinsip tersebut telah menginternalisasi dalam kehidupan pergaulan dan aktifitas sehari-hari antar semua unsur di dalam LPKA Blitar. Hal ini sudah sejalan dengan pasal 85 ayat (1-3) UU Nomor 11 Tahun 2012, yang meliputi hak pertumbuhan, perkembangan anak, fisik, mental, dan sosial. Dalam pasal 14 ayat 1 dan 2 UU No 35 tahun 2014 tentang perubahan atas UU No 23 tahun 2003 tentang perlindungan anak, bahwa anak berhak diasuh oleh orang tuanya sendiri namun dalam keadaan tertentu pemisahan dimungkinkan demi kepentinagn terbaik bagi anak tanpa menghalangi kesempatan anak bertemu 
dengan keluarganya sebagaimana yang berjalan selama di LPKA ada jam berkunjung dari keluarga dan kolega.

Ketiga, dari segi kerjasama eksternal, LPKA Blitar telah melaksanakan kerjasama lintas instansi pemerintah tersebut merupakan penerapan dari pasal 22 UU Nomor 35 tahun 2014 tentang Perubahan atas UU No 23 tahun 2002 tentang Perlindungan Anak dinyatakan bahwa negara, pemerintah dan pemerintah daerah berkewajiban dan bertanggungjawab memberikan dukungan sarana, prasarana, dan ketersediaan sumberdaya manusia dalam penyelenggaraan perlindungan anak. Demikian juga dalam pasal 25 ayat (1) UU Nomor 35 tahun 2014 menyebutkan kewajiban tanggungjawab masyarakat terhadap perlindungan anak dilaksanakan melalui peran serta masyarakat dalam penyelenggaraannya, termasuk melibatkan organisasi kemasyarakatan, akademisi dan pemerhati anak.

\section{Penutup}

Pelaksanaan hak pendidikan anak didik pemasyarakatan LPKA Blitar yang divonis telah bersama-sama melakukan pembunuhan santri di Lamongan dapat dilihat dari 3 ( tiga) aspek: pola sistem perlakuan anak didik pemasyarakatan, prinsip-prinsip pembinaan anak didik pemasyarakatan, dan kerjasama dan kemitraan.

Pola sistem perlakuan anak didik LPKA telah dilaksanakan sesuai tahapannya: mereka diberi kesempatan bersekolah di SMA YP yang menginduk kepada SMA YP kota Blitar, dan dilaksanakan di dalam LPKA yakni kelas X, XI dan XII, bagi anak kelas XII diikutsertakan UNAS dan dinyatakan lulus dengan baik, sedangkan untuk program tahfidh al-Qur'an, maka diikutkan pendidikan Madrasah Diniyah (MADIN) di dalam LPKA Blitar.

Dalam hal prinsip pembinaan terhadap anak didik pemasyarakatan, LPKA Blitar telah mengaplikasikan 10 (sepuluh) prinsip pembinaan yang tertuang dalam Piagam Arcamanik hasil konfrensi "Perubahan Sistem Perlakuan terhadap Anak yang berhadapan dengan Hukum yang Ramah Anak Berbasis Budi Pekerti”.

Implementasi yuridis mengenai sistem perlakuan terhadap 11 (sebelas) anak didik pemasyarakatan yang menjalani pidana di LPKA 
Blitar karena vonis hakim terlibat kasus pembunuhan santri di Lamongan, prinsip pembinaan terhadap mereka, dan kerjasama dalam pelaksanaan pembinaan anak didik tersebut dapat dikatakan telah memenuhi ketentuan perundang-undangan mengenai perlindungan hak-hak anak selama menjalani masa pidana di LPKA, antara lain mengacu pada pasal 1, 2, 3, 4, 85, 86 UU Nomor 11 tahun 2012 tentang Sistem Peradilan Pidana Anak dan pasal 14 ayat $(1,2)$ pasal 22, dan pasal 25 ayat (1) UU Nomor 35 tahun 2014 tentang Perubahan Atas Undang Undang Nomor 23 tahun 2002 tentang Perlindungan Anak.

\section{Daftar Pustaka}

Eko Sudjarwo, "16 Santri Aniaya Temannya Hingga Tewas, Ponpes di Lamongan Angkat Bicara"

Eko Sudjarwo, "Seorang Santri Ponpes di Lamongan Tewas Dianiaya Temannya", https://news.detik.com/berita-jawatimur/d-3369896/seorang-santri-ponpes-di-lamongantewas-dianiaya-temannya, diakses pada 7 November 2018.

Eric lambue Tampubolon dan Chalid Sahuri, "Efektivitas Pembinaan Narapidana Anak di Lembaga Pembinaan Khusus Anak (LPKA) Pekanbaru", Jom VISIP, Volume 4 No. 1 Februari 2017.

Estu Putri Wilujeng, "Konsep Diri Anak yang Berkonflik dengan Hukum (Studi Kualitatif tentang Anak yang Berkonflik dengan Hukum pada Rumah Tahanan Klas I Surabaya, Medaeng - Sidoarjo)", Makalah, (Surabaya: Departemen Sosiologi Fakultas Ilmu Sosial dan Ilmu Politik Universitas Airlangga).

Kautsar Muhammad al-Mainawi, Hak Anak dalam Keluarga Muslim, terj. Moh Suri Sudari (Jakarta: Pustaka al-Kautsar, 1996).

M. Nasir Djamil, Anak Bukan Untuk Dibukum, Jakarta: Sinar Grafika Offfset, 2013.

Maidin Gultom, Perlindungan Hukum terhadap Perempuan dan Anak, Bandung: Rafika Aditama, 2012.

Maulana Abul A'la Al-Maududi, Hak-hake Asasi Manusia dalam Islam, ter. Bambang Iriana Djayaatmadja, Jakarta: Bumi Aksara,t.t.

Nidlam (ANDIKPAS kasus pembunuhan santri Lamongan sebagai ketua kelompok), Wawancara, Blitar, 10 Agustus 2017. 
Purnianti, dkk. Analisa Sistem Peradilan Pidana Anak (Juvenile Justice System) di Indonesia, (UNICEF Indonesia: 2006).

Putusan PN Lamongan Nomor 14/Pid.Sus-Anak/2016/PN.Lmg Tahun 2017.

Resolusi PBB No 45/112 tahun 1990 tentang pedoman PBB dalam rangka Pencegahan Tindak Pidana Remaja, pasal 46.

Siti Dalilah Candrawati "Konvensi Hak Anak Perspektif Islam", Jurnal al-Qanun, Vo. 5, Juni 2003.

UU Nomor 11 tahun 2012 tentang Sistem Peradilan Pidana Anak.

Dokumen LPKA Blitar tentang "Piagam Acamanik", Bandung, 4 Agustus 2015.

Al-Qur'an dan Terjemahnya, (Jakarta: Yayasan Penyelenggara Penterjemah/Penafsir al-Qur'an, 1971).

Andik (Kepala seksi Pendidikan dan Pelatihan LPKA Blitar), Wawancara, Blitar, 10 Agustus 2017.

Sri Lestari, Wakil Ketua PD 'Aisyiyah kota Blitar, Wawancara, 10 Agustus 2017.

"Anak masih Berpotensi Masuk Rumah Tahanan", dalam http://icjr.or.id/anak-masih-berpotensi-masuk-rumahtahanan/ diakses pada 11 November 2018.

"Berkas Perkara Tewasnya Santri di Lamongan Dilimpahkan ke Kejaksaan", https://news.detik.com/berita-jawa-timur/d3375535/berkas-perkara-tewasnya-santri-di-lamongandilimpahkan-ke-kejaksaan, diakses pada 6 November 2018. https://news.detik.com/berita-jawa-timur/d-3371245/16-santrianiaya-temannya-hingga-tewas-ponpes-di-lamongan-angkatbicara, diakses pada 6 November 2018. 